\title{
A Study of Magnitude of Direct and Indirect Effect Relationship in Saffron (Croccus sativus L.)
}

\author{
F.A. Sheikh*, M.I. Makhdoomi, F.A. Nehvi, Ajaz A. Lone, Gowhar Ali and M.A. Bhat \\ Division of Genetics and Plant Breeding, Sher-e-Kashmir University of Agricultural Science and \\ Technology, FOA, Wadura, Sopore, SKUAST-K, Jammu and Kashmir-190025, India \\ *Corresponding author
}

\section{A B S T R A C T}

\begin{tabular}{|l|}
\hline K e y w o r d s \\
$\begin{array}{l}\text { Croccus sativus, } \\
\text { Path coefficient } \\
\text { analysis, } \\
\text { Direct effect, } \\
\text { Indirect effect. }\end{array}$ \\
\hline Article Info \\
\hline $\begin{array}{l}\text { Accepted: } \\
\text { 04 April } 2017 \\
\text { Available Online: } \\
\text { 10 May } 2017\end{array}$ \\
\hline \hline
\end{tabular}

\begin{abstract}
The research carried out during 2010 at Saffron Research Station Pampore, SKUASTKashmir to investigate the yield relationships between yield and some yield related components of fifty clones of saffron (Croccus sativus L.) by using path coefficient analysis. All the clones were replicated thrice with plant geometry of $20 \times 10 \mathrm{~cm}$. Observations were recorded on 10 randomly selected and tagged competitive plants for morphological, physiological, floral and corm attributes. The path analysis revealed that pistil length recorded highest direct effect towards fresh pistil weight followed by plant height and stigma length. Rest of the traits as number of flowers recorded weak positive direct effects and the negative direct effect of number of radical leaves plant- 1 on the dependant variable. However in case of corm attributes in saffron (Crocus sativus L.), average weight of daughter corms per mother corm exerted negative direct effect on number of daughter corms per mother corm while as size of stomata showed strong positive direct effect on number of daughter corms per mother corm. Based on findings of present investigation possibility of saffron improvement is indicated through clonal selection from the available germplasm resources.
\end{abstract}

\section{Introduction}

Saffron (Crocus sativus) is a bulbous perennial of the iris family (Iridaceae) treasured for its golden-colored, pungent stigmas, which are dried and used to flavor and color foods as well as a dye. It has a distinct and unique color, flavor and aroma and some of the groups of chemical compounds responsible for each of these properties have now been identified. One of its principal coloring pigments is crocin, which is easily soluble in water. In addition to crocin, saffron contains crocetin as a free agent and small amounts of the pigment anthocyanin, a-carotene, b-carotene and zeaxantin (Abdullaev, 1993; Tarantilis and Polissiou, 1997). The Short Communication stigmas of saffron flower has been used as medicinal herbolary from ancient times, as it is a rich source of carotenoids due to which it has anti-cancer and antitumor effects and is also used to treat various human health conditions such as coughs, flatulence, stomach disorders, colic, insomnia, smallpox, asthma and cardiovascular disorders (Abdullah, 2004; Fernandez, 2004). Saffron is a spice known only in cultivation and principally grown in Spain and Iran, but also cultivated on a lower scale in Greece, Turkey, 
India, Azerbaijan, France, Italy, India, China, Morocco, Turkey, Israel, Egypt, United Arab Emi rates, Mexico, Switzerland, Algeria, Australia, and New Zealand (Abdullaev, 1993, 2002) In India saffron is exclusively cultivated in Jammu and Kashmir with new reports from Himachal Pradesh and Uttrakhand, its cultivation around Pampore in Kashmir valley date back to around $500 \mathrm{BC}$. The knowledge on the extent of variation and identification of a good number of genotypes as potential donors in yield improvement programme is essential. Equally important is the information on indirect (correlation and path coefficients) selection parameters so as to formulate a coherent breeding programme for future use. The method of path coefficients proposed by Wright in 1921 has been employed to study the direct and indirect effect of various traits on the ultimate product of economic importance in several crops. With this aim, a set of saffron clones was used to study the cause and effect relationship towards yield and possibility of developing high yielding saffron varieties from the available gene pool which provides ample opportunity to affect the vertical improvement in terms of developing saffron varieties, which demonstrate high yielding ability and quality.

\section{Materials and Methods}

Fifty clones were selected from the available germplasm to investigate the yield relationships between yield and some yield components of saffron (Croccus sativus L.) by using path coefficient analysis at Saffron Research Station (Dossu) Konibal, a substation of Shere-Kashmir University of Agricultural sciences and Technology Kashmir. The clones were planted in a randomized block design with three replications with intra/interspacing of 10 and $20 \mathrm{~cm}$ respectively during2010. Observations were recorded on 10 randomly selected and tagged competitive plants for the characters, viz., No of leaves/plant, plant height (cm),number of flowers/corm, pistil length $(\mathrm{cm})$, stigma length $(\mathrm{cm})$, fresh pistil weight per corm (mg), stomatal frequency, average weight of daughter corms mothercorm $(\mathrm{g})$, size of stomata and chlorophyll content (\%).

\section{Results and Discussion}

The present investigation was carried out to generate information on cause and effect relationship. The degree of relationship through the estimation of correlation coefficient simply measures the nature of symmetrical association between various characters. Based on the prior knowledge of relationship between independent and dependent variables a casual scheme was formulated. In one scheme number of radical leaves/plant, plant height, number of flowers/corm, pistil length and stigma length were taken as independent variables and their contribution towards fresh pistil weight percorm (dependent trait) was determined. Whereas, in another scheme stomatal frequency, average weight of daughter corms mother corm, size of stomata and chlorophyll content were taken as independent variables with number of daughter corms/mother corm as a dependent variable. The direct and indirect effect of five different yield attributing traits towards fresh pistil weight were estimated through partitioning of their genotypic correlation coefficients using path coefficient analysis and the results are presented in table 1 and depicted in figure 1. The analysis has that revealed that pistil length (0.3805) recorded highest direct effect towards fresh pistil weight followed by plant height and stigma length. Rest of the traits as number of flowers recorded weak positive direct effects and the negative direct effect of number of radical leaves/plant on the dependent variable. The weak direct effect of number of $\mathrm{f}$ lowers/corm was nullified on account of strong indirect effect via pistil length and stigma length. 
Table.1 Direct (diagonal) and indirect (off-diagonal) effects of important traits on fresh pistil weight (mg) in saffron (Crocus sativus L.)

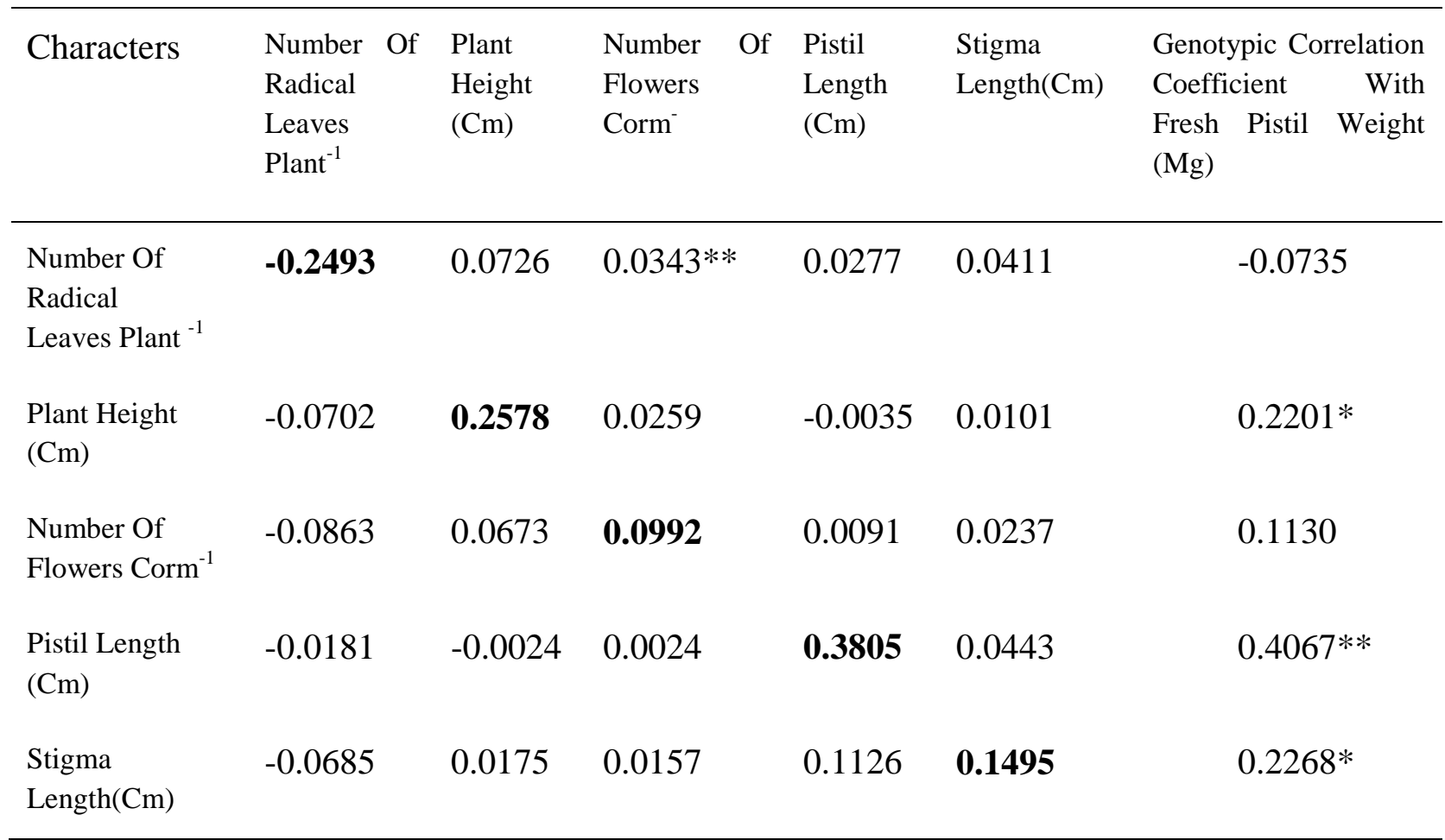

Significant at 5 and 1 per cent levels, respectively; R SQUARE=0.4685, RESIDUAL EFFECT=0.2998.

Table.2 Direct (diagonal) and indirect (off-diagonal) effects of important traits on number of daughter corms / mother corm in saffron (Crocus sativus L.)

\begin{tabular}{|c|c|c|c|c|c|c|c|}
\hline Characters & $\begin{array}{l}\text { Stomatal } \\
\text { frequency }\end{array}$ & $\begin{array}{l}\text { Average } \\
\text { of } \\
\text { corms } \\
\operatorname{corm}(g)\end{array}$ & $\begin{array}{r}\text { weight } \\
\text { daughter } \\
/ \text { mother }\end{array}$ & $\begin{array}{l}\text { Size of } \\
\text { stomata } \\
\text { (microns) }\end{array}$ & $\begin{array}{l}\text { Chlorophyll } \\
\text { content }(\%)\end{array}$ & $\begin{array}{l}\text { Genotypic } \\
\text { coefficient } \\
\text { daughter } \\
\text { corm }\end{array}$ & $\begin{array}{l}\text { correlation } \\
\text { with Number of } \\
\text { corms/ mother }\end{array}$ \\
\hline Stomatal frequency & 0.2286 & & -0.0672 & 0.2247 & 0.0586 & & $0.4446 * *$ \\
\hline $\begin{array}{l}\text { Average weight of daughter } \\
\text { corms mother } \operatorname{corm}^{-1}(\mathrm{~g})\end{array}$ & 0.1049 & & -0.1464 & 0.0582 & -0.0103 & & 0.0065 \\
\hline Size of stomata (microns) & 0.1333 & & -0.0221 & 0.3851 & 0.0179 & & $0.5142 * *$ \\
\hline Chlorophyll content (\%) & 0.0562 & & 0.0063 & 0.0289 & 0.2382 & & $0.3296 * *$ \\
\hline
\end{tabular}

Significant at 5 and 1 per cent levels, respectively; R SQUARE $=0.4685$, RESIDUAL EFFECT $=0.299$ 
Fig.1 An outline of path diagram depicting inference of various factors on fresh pistil weight

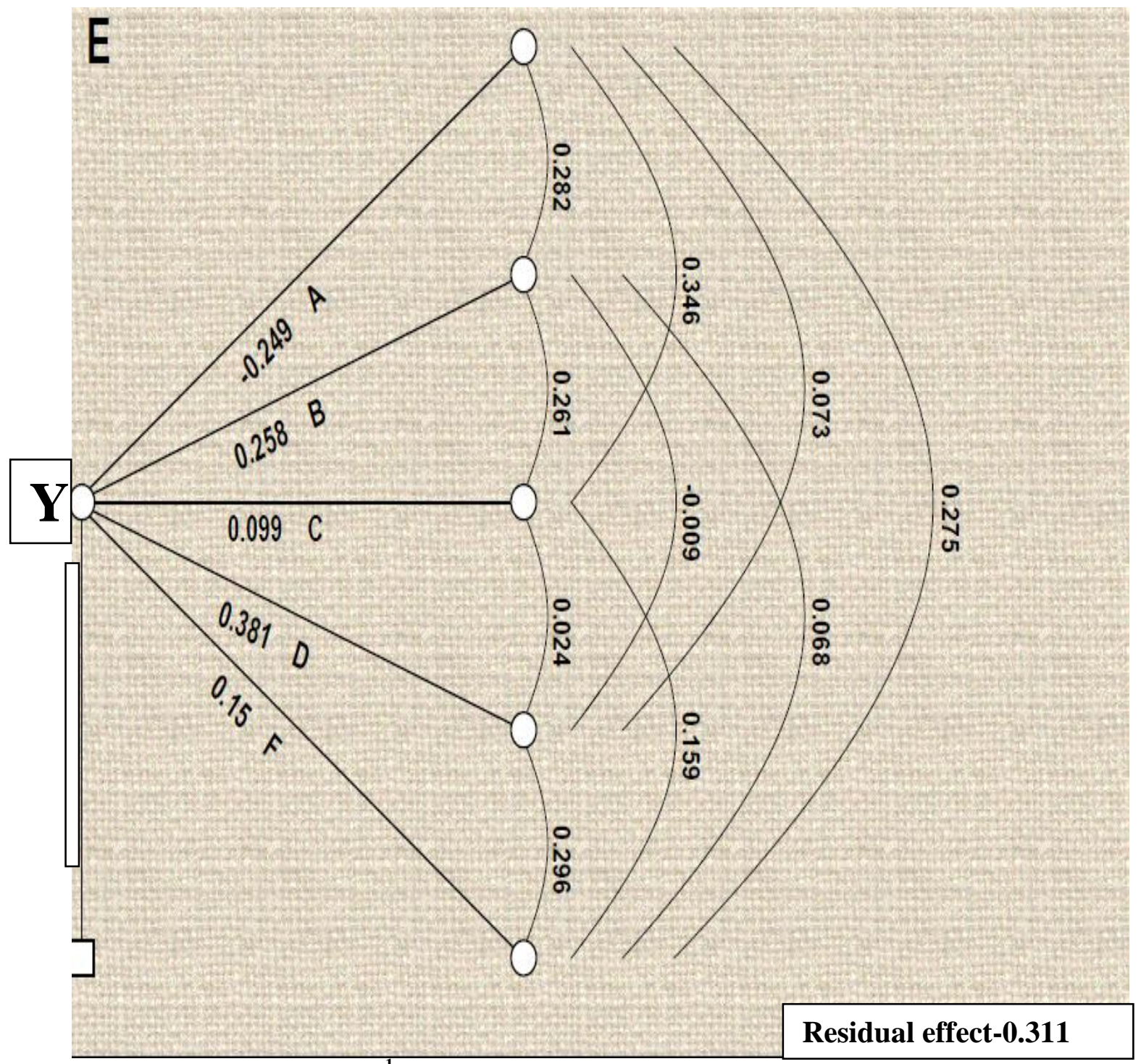

(1) Number of radical leaves plant ${ }^{-1}$

(2) plant height (cm)

(3) Number of flowers corm $^{-1}$

(4) Pistil length (cm)

(5) Stigma length $(\mathrm{cm})$

Y: Fresh pistil weight 
Fig.2 An outline of path diagram depicting inference of various factors on number of daughter corms/mother corm

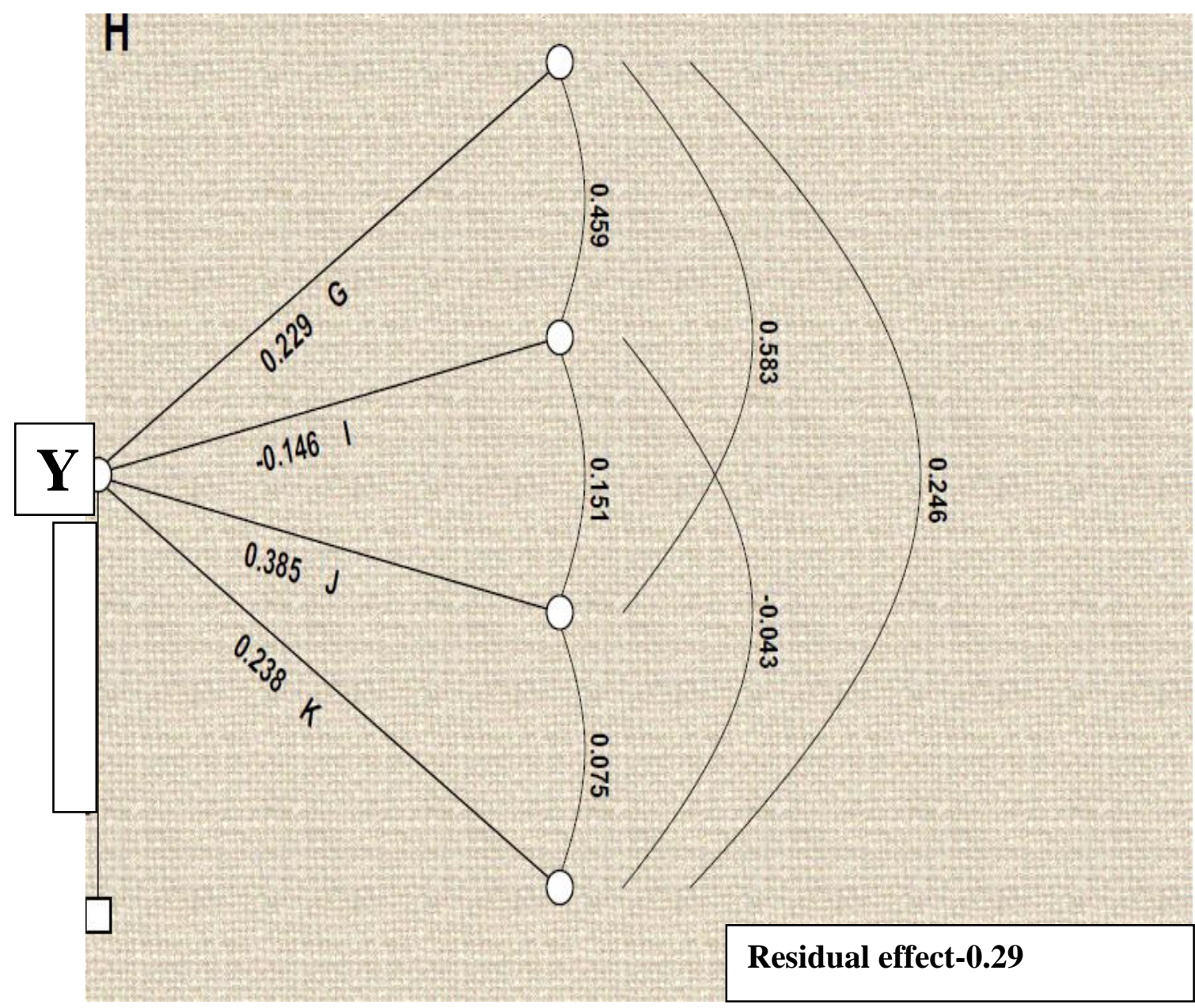

(1) Stomatal frequency

(2) Average weight of daughter corms mother $\operatorname{corm}^{-1}(\mathrm{~g})$

(3) Size of stomata (microns)

(4) Chlorophyll content (\%);

Y: Number of daughter corms/mother corm

Similarly the direct and indirect effect of four different corm attributing traits towards number of daughter corms/mother corm were estimated through partitioning of their genotypic correlation coefficients using path coefficient analysis at genotypic level and the results are presented in table 2 and depicted in figure 2 . The results have revealed that the stomata size $(0.3821$ microns $)$ recorded highest direct effect towards number of daughter corms/mother corm followed by chlorophyll content and stomatal frequency.
The average weight of daughter corms per mother corm indicates negative direct effect on the number of daughter corms (dependant trait). The negative direct effect was nullified by the positive effect of morphological independent traits. Path coefficient analysis in gladiolas by Sadhu et al., (1990) revealed that $\mathrm{f}$ lower size and duration of $\mathrm{f}$ lowering recorded maximum direct effect on yield whereas Hedge et al., (1997); Anurdha et al., (2000) and Neraj et al., (2001) recorded maximum positive direct effect by plant 
height in the same crop. Path coefficient analysis indicated that pistil length was the major determinant of saffron yield corm-1. Based on findings of present investigation possibility of saffron improvement is indicated through clonal selection from the available germplasm resources as being envisaged by Agayev et al., (2009) and Gowhar et al., (2013). Identification of elite genotypes with distinct superiority in yield and corm attribute can act as a source for further improvement and development of high yielding varieties which can be beneficial for saffron industry in Jammu and Kashmir, particularly to the marginal and small farmers associated with saffron cultivation by increasing their net returns from saffron and encourage farmers from nontraditional areas to take up saffron cultivation. Development of varieties from the identified germplasm resources, exhibiting high yielding potential and quality will boost the production and productivity of saffron in Jammu and Kashmir State and improve the socioeconomic well being of the people associated with this important commercial crop.

\section{References}

Abdullaev, F.I. 1993. Biological effects of saffron. Biofactors, 4: 83-86.

Abdullaev, F. 2002. Cancer chemo preventive and tumoricidal properties of saffron. Crocus sativus L. Exp. Biol. Med., 227: 20-25.

Agayev, Y.M.O., Fernandez, J.A. and Zarifi, E. 2009. Clonal selection of saffron. Crocus sativus L.): the first optimistic experimental results. Euphytica, 169: 8199.

Anuradha, S., Gowda, J.V.N. and Jaya Prasad, K.V. 2000. Path coeff icient analysis for floral traits in gladiolus. Crop Res., 19(1): 70-73.

Gowhar, A., Asif, M., Iqbal, F.A., Nehvi, Sheikh Sameer Samad, Shaheena Nagoo, Sabeena, N. and Niyaz, A., Dar. 2013. Prospects of clonal selection for enhancing productivity in Saffron. Crocus sativus L. African J. Agri. Res., 8(5): 460467.

Hegde, M.V., Rajendra Passannavar, R. and Shenoy, H. 1997. Path analysis studies in gladiolus. Adv. Agri. Res. India, 8: 37-39.

Neeraj Misra, H.P. and Jha, P.B. 2001. Correlation and path coefficient analysis in gladiolus. J. Ornamental Horticulture, 4(2): 74-78.

Nehvi, F.A., Wani Shafiq, A., Dar, S.A., Makhdoomi, M.I., Allie, B.A. and Mir, Z.A. 2006a. New Emerging Trends on Production Technology of saffron. Proc. 2nd International symposium on Saffron Biology and Biotechnology, 28- 30 October 2006. Islamic Republic of Iran.

Sandhu, G.P.S., Sharma, S.C. and Arora, J.S. 1990. Association among morphological traits in gladiolus. Punjab Horticultural J., 30(1-4): 191-195.

Tarantilis, P.A. and Polissiou, M. 1997. Isolation andidentification of the aroma constituents of saffron. Crocussativa $L$. J. Agric Food Chem., 45: 459-462.

Wright, S. 1921. Correlation and causation. $J$. Agri. Res., 20: 557-585.

\section{How to cite this article:}

Sheikh, F.A., M.I. Makhdoomi, F.A. Nehvi, Ajaz A. Lone, Gowhar Ali and Bhat, M.A. 2017. A Study of Magnitude of Direct and Indirect Effect Relationship in Saffron (Croccus sativus L.). Int.J.Curr.Microbiol.App.Sci. 6(5): 175-180. doi: http://dx.doi.org/10.20546/ijcmas.2017.605.020 